\title{
The toxicology properties of modified hydrothermal nanotitania extraction
}

\author{
Ahmad Mukifza Harun¹, Nor Farid Mohd Noor², Ramizu Shaari², Lio Xing Ying², \\ Mohamad Ezany Yusoff², Mohammad Khursheed Alam ${ }^{3}$
}

\author{
${ }^{1}$ Engineering Faculty, Universiti Malaysia Sabah, Jalan UMS, Kota Kinabalu, Sabah, Malaysia \\ ${ }^{2}$ School of Dental Science, Universiti Sains Malaysia, Health Campus, Kubang Kerian, \\ Kelantan, Malaysia \\ ${ }^{3}$ Department of Orthodontic, College of Dentistry, Jouf University, Sakaka, Kingdom of Saudi \\ Arabia
}

Submitted: 31 March 2020; Accepted: 1 September 2020

Online publication: 8 January 2021

Arch Med Sci 2022; 18 (5): 1338-1341

DOI: https://doi.org/10.5114/aoms/127086

Copyright @ 2020 Termedia \& Banach

\section{Abstract}

Introduction: The nanoparticle has become a part of world industry. This substance has been proven as potentially beneficial for its usage as a catalyst and semi-conductor due to its high surface area and the effects of the quantum size effect. It exhibits potential characteristics and would be applied in a wider scope of usage compared to bulk particles because the smaller the size of the particles, the more room for the extent of their usage. Nano titanium dioxide application as semi-conductors together with a catalyst is highly attributed to its high photochemical stability and ability to be produced at a low-cost. The consequence of this - exposure of nano titanium dioxide particles to humans - raises concerns regarding health and safety. Therefore, this research action works designed to offer a thorough analysis of toxicology impacts produced by our own synthesis modified hydrothermal in vitro experiments.

Material and methods: Our nanotitania extraction with $0.05 \%$ silver was tested for its toxicity against $L 929$ mouse cells. The cytotoxicity effect of nanotitania extract was evaluated by MTT assay. Cell viability (\% CV) was calculated using a formula.

Results: There are non-cytotoxicity activity of $0.05 \%$ nanotitania at concentrations $1.5,3.1,6.3,12.5$, and $25 \mathrm{mg} / \mathrm{ml}$ on 1929 cell lines except at concentration 50 and $100 \mathrm{mg} / \mathrm{ml}$. The result was related to the optical density reading.

Conclusions: There is no cytotoxic effect of nanotitania extraction with $0.05 \%$ silver in the growth inhibition test with 1929 mouse with the exception of the $100 \mathrm{mg} / \mathrm{ml}$ extract.

Key words: nanotitania extraction, toxicology test, silver.

\section{Introduction}

Titanium dioxide $\mathrm{TiO}_{2}$ is a substance used extensively nowadays in various fields, for example as an antibacterial agent [1]. It is still being studied regarding its usage and potential use in the future. Its various effects on the environment are being monitored extensively to detect possible complications of its usage.

Nowadays $\mathrm{TiO}_{2}$ is being used in the food industry as a food additive. The effect of $\mathrm{TiO}_{2}$ on the gastrointestinal system as a food additive has

\section{Corresponding author:}

Ahmad Mukifza Harun

Engineering Faculty

Universiti Malaysia Sabah

Jalan UMS

88400 Kota Kinabalu

Sabah, Malaysia

E-mail:mukifza@ums.edu.my 
been considered safe and shows no major effect in vitro on intestinal bacteria such as Bacteroides ovatus and Clostridium cocleatum, suggesting its safety for use in the intestine [2]. Besides that, the various and different forms of titanium dioxide $\left(\mathrm{TiO}_{2}\right)$ may influence its action in the human body [3].

Interestingly, various studies have suggested a negative influence of $\mathrm{TiO}_{2}$. A study on Balb/c mice showed the effect of nano-titanium dioxide caused cytotoxicity and possible effect to the cardiovascular system of the mice, which is shown to be countered by vitamin E [4]. In addition, nano-titanium dioxide produced by sol-gel method showed an impact on earthworm Eudrilus euginiae proliferation and the survival possibly of reactive oxygen species (ROS) formation from $\mathrm{TiO}_{2}$ [5]. Furthermore, nutritional starvation and drought stress are 2 effects of $\mathrm{TiO}_{2}$ on the plant stress response [6]. Interestingly, an in vitro test using alveolar epithelial cells and macrophage showed decreased reactive oxygen species (ROS) by adding silica to the $\mathrm{TiO}_{2}$, which was suggested to modify the effect of the $\mathrm{TiO}_{2}$ [7].

A study of the effect of nanotitania on the aquatic ecosystem revealed a negative effect of the $\mathrm{TiO}_{2}$ on the nucleus and cell membrane together with organelle damage to the freshwater algae [8]. Specifically, the order Cladocera aquatic species is speculated to be prone to be affected by $\mathrm{TiO}_{2}$ phototoxicity [9].

This substance was developed to be used as an antimicrobial agent. Our substance has been tested against the growth of Staphylococcus aureus in the lab [10]. In addition, it has been shown to have no mutagenic effect by using Ames test for genotoxicity test [11]. In this study, our nanotitania extraction with $0.05 \%$ silver was tested against L929 mouse cells, aimed at testing its toxicology effects in in vitro experiments.

\section{Material and methods}

\section{Material preparation}

The nanotitania extraction with $0.05 \%$ silver was developed by Universiti Malaysia Sabah (UMS), as mentioned in a previous publication [12]. Our extraction is non-water based; it is dimethyl sulphoxide (DMSO) non-dilution. The extracted nanotitania have been experimented using high-resolution scanning electron microscopy (SEM), high-resolution transmission electron microscopy for the particle crystallinity quality, and X-ray diffractometer for nanotitania anatase confirmation.

\section{Cytotoxicity evaluation of nanotitania extract}

The cytotoxic effect of nanotitania extract was evaluated by MTT assay. The sample nanotitania extract with $0.05 \%$ silver was sterilised using autoclave at $121 \pm 1^{\circ} \mathrm{C}$ for $20 \mathrm{~min}$. Mouse Fibroblast cell line (L929) was plated in 96-well plates at $1 \times 10^{4}$ cell density in completed growth medium and subject to incubating process at $37 \pm 1^{\circ} \mathrm{C}$ for $24 \pm 2 \mathrm{~h}$. Then $100 \mu \mathrm{l}$ extracted solution of material at 100, 50, 25, 12.5, 6.3, 3.1, and $1.5 \mathrm{mg} / \mathrm{ml}$ was replaced in the 96 -well plates and incubated at $37 \pm 1^{\circ} \mathrm{C}$ for $24 \pm 2 \mathrm{~h}$. Zinc sulphate was used $(0.46,0.23,0.115,0.058,0.029,0.014$, $0.007 \mathrm{mg} / \mathrm{ml}$ ) as a positive control material. After $24 \mathrm{~h}, 10 \mu \mathrm{l}$ of the MTT solution was added to each well and was subjected to $4 \mathrm{~h}$ of incubation. Cell with media only were used as a negative control. Post-incubation (4 h), $100 \mu$ l solution was eliminated from each well and swapped with $100 \mu \mathrm{l}$ of DMSO. The plate was shaken using a shaker at $300 \mathrm{rpm}$ for $15 \mathrm{~min}$, and the outcome was read out using an ELISA reader spectrophotometer at $570 \mathrm{~nm}$ wavelength.

The cell viability (CV) was calculated according to the following formula:

$$
\% \mathrm{CV}=\frac{\begin{array}{c}
\text { Averages absorbance of sample } \\
\text { wells }
\end{array}}{\begin{array}{c}
\text { Average absorbance of control } \\
\text { negative wells }
\end{array}} \times 100
$$

The negative control used in this test was a medium of cell culture known as Dulbecco's Modified Eagle Medium (DMEM + 10\% FCS), incubated for $24 \mathrm{~h}$ under the same conditions as the extract.

The positive control used in this test was a dilution series of zinc sulphate $(0.46,0.23,0.115$, $0.058,0.029,0.014,0.007 \mathrm{mg} / \mathrm{ml})$, incubated for $24 \mathrm{~h}$ under the same conditions as the extract.

\section{Statistical analysis}

Statistical assessment of the data was achieved by using one-way analysis of variance (ANOVA) using SPSS version 26.0 software to evaluate the significance of different concentrations of $0.05 \%$ nanotitania extract to $\mathbf{L 9 2 9}$ cell lines. The significant discrepancy between different concentrations of $0.05 \%$ nanotitania extraction for cytotoxicity valuation with $p<0.05$ was considered significant. Non-linear regression analysis of Graphpad Prism software version 6 was used to determine the $\mathrm{IC}_{50}$ value.

\section{Results}

Cytotoxic effect and $\mathrm{IC}_{50}$ of $0.05 \%$ nanotitania on normal cell lines

The cytotoxic effects of $0.05 \%$ nanotitania was analysed on $\mathrm{L} 929$ cell lines with different concentrations for $24 \mathrm{~h}$ of incubation period. The cytotoxic effect of the samples was evaluated using MTT assay. The cell viability of cell lines used in 


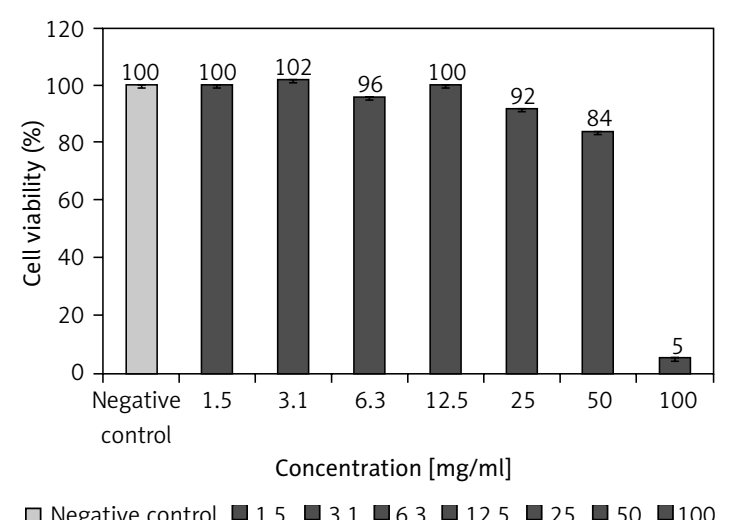

Figure 1. Cytotoxicity effects of $0.05 \%$ nanotitania extract at concentration $1.5-100 \mathrm{mg} / \mathrm{ml}$ on $\mathrm{L} 929$ cells after 24-hour incubation. Each value represents mean \pm SEM of 10 wells per concentrations in triplicates. A significant difference with negative control with $p<0.05$ compared to negative control (NEG)

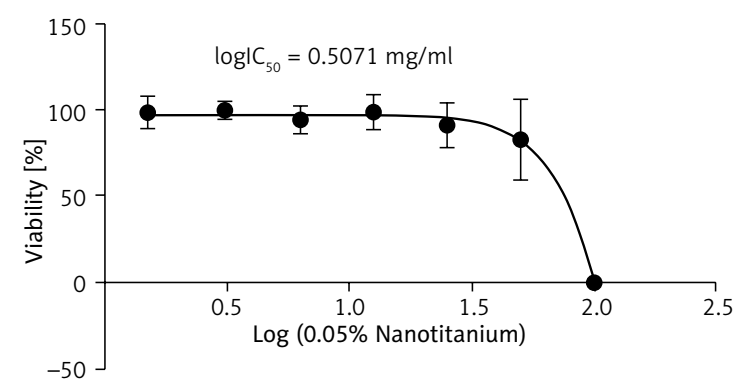

Figure 2. Determination of $\mathrm{IC}_{50}$ using MTT assay at $24 \mathrm{~h}$. The curve was constructed by GraphPad Prism software version 6 using non-linear regression analysis to construct the curve of $0.05 \%$ nanotitania extract at different concentrations and the provided inhibitory effect on $L 929$ cells with an $\mathrm{IC}_{50}$ value of $3.215 \mathrm{mg} / \mathrm{ml}$ at $24 \mathrm{~h}\left(R^{2}=0.9157\right)$

this study was above $70 \%$ confluent before treatment. Our results show that most of the nanotitania dilutions $(1.5,3.1,6.3,12.5$ and $25 \mathrm{mg} / \mathrm{ml})$ were not significantly changed compared to negative control.

The $0.05 \%$ nanotitania at concentrations of $1.5,3.1,6.3,12.5$, and $25 \mathrm{mg} / \mathrm{ml}$ is explained as follows: after the nanotitania extraction was made, it was observed that at certain values of e.g. temperature, acid molarity, and mass ratio, the growth of nanotitania is at its optimum. In order to produce good, high crystallinity nanoparticles, a method of modified hydrothermal imposed with molten salt method was introduced during the extraction synthesis. For this molten salt process, a silver nitrate was used, added by $0.05 \%$ by weight to the extracted nanotitania.

Only the concentrations of 50 and $100 \mathrm{mg} / \mathrm{ml}$ were significantly distinct compared to the negative control in Figure 1 . This result revealed that there was non-cytotoxicity activity of $0.05 \%$ nanotitania at concentrations $1.5,3.1,6.3,12.5$,
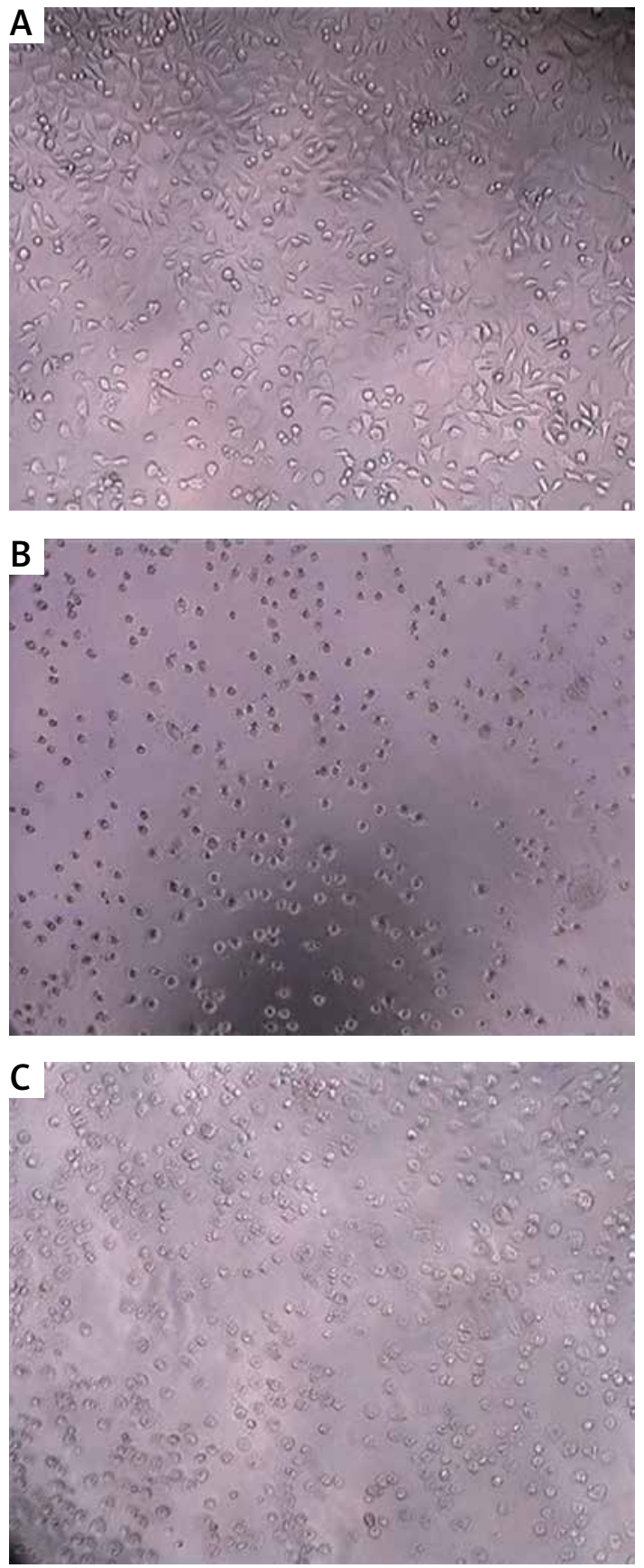

Figure 3. Morphological changes of the L929 cell after treatment with $0.05 \%$ nanotitania extract. A-negative control, B-positive control, C-100 mg/ ml extract. Scalebar: $200 \mu \mathrm{m}$

and $25 \mathrm{mg} / \mathrm{ml}$ on $\mathrm{L} 929$ cell lines, but not at concentrations 50 and $100 \mathrm{mg} / \mathrm{ml}$. The result was related to the $O D$ (optical density) reading, in which a higher OD reading indicated that a higher percentage of viable cells, and a lower OD reading indicated a lower percentage. Furthermore, the inhibitory effect of $0.05 \%$ nanotitania at different concentrations with an $I C_{50}$ value of $3.215 \mathrm{mg} / \mathrm{ml}$ at $24 \mathrm{~h}\left(R^{2}=0.9157\right)$ is shown in Figure 2. 


\section{Evaluation of morphological changes of $\mathrm{L} 929$ cell line treatment with $0.05 \%$ nanotitania extract}

Morphological changes of normal L929 cell line treated with $0.05 \%$ nanotitania extract at different concentrations $(1.5-100 \mathrm{mg} / \mathrm{ml})$ for $24 \mathrm{~h}$ were observed using an inverted microscope. Nanotitania extract with $0.05 \%$ silver had no cytotoxic effect in the growth inhibition test with L929 mouse except for the $100 \mathrm{mg} / \mathrm{ml}$ extract (Figure 3).

The International Organisation for Standardisation (ISO 10993-5:2009) guideline was applied in the reporting of morphological changes.

\section{Discussion}

Hence, another test on cell viability and reactivity is done by using $0.05 \%$ silver in $\mathrm{TiO}_{2}$. The results of the material nanotitania with a combination of $0.05 \%$ silver in different concentrations is thought to show no cytotoxic effect in the growth inhibition test with $L 929$ mouse besides the $100 \mathrm{mg} / \mathrm{ml}$ extract. Therefore, it means that $\mathrm{TiO}_{2}$ with a combination of $0.03 \%$ silver (which has a lower concentration) logically and inevitably has no cytotoxic effect and is safe to be used in future.

For the future benefit, it is best to suggest that this nanotitania be extracted via modified hydrothermal improve with molten salt process study under various virology tests to observe its disinfection ability. The limitation of this study was the ability to produce the substance on a mass scale, which is restricted by our small laboratory together with the very intense processes in producing it.

Apart from that, the non-cytotoxicity characteristic of the nanotitania is our main concern as well, to make sure itis safety for all clinicians and their patients in future. It also can be concluded that the process of producing the nano titanium dioxide a safe process overall.

In conclusion, nanotitania extract with $0.05 \%$ silver has no cytotoxic effect on the growth inhibition test with 1929 mouse, except for the $100 \mathrm{mg} / \mathrm{ml}$ extract.

\section{Acknowledgments}

Mr Zawdy Badruddin (staff of School of Dental Sciences, USM Health Campus) for the photostaken.

\section{Conflict of interest}

The authors declare no conflict of interest.

\section{References}

1. Ahmad R, Sardar M. TiO2 nanoparticles as an antibacterial agents against E. coli. Int J Innov Res Sci Eng Technol 2013; 2: 3569-74.
2. Dudefoi W, Moniz K, Allen-Vercoe E, Ropers MH, Walker VK. Impact of food grade and nano- $\mathrm{TiO}_{2}$ particles on a human intestinal community. Food Chem Toxicol 2017; 106: $242-9$.

3. Uboldi C, Urbán P, Gilliland D, et al. Role of the crystalline form of titanium dioxide nanoparticles: rutile, and not anatase, induces toxic effects in Balb/3T3 mouse fibroblasts. Toxicol In Vitro 2016; 31: 137-45.

4. Zhang Q, Liu Z, Du J, et al. Dermal exposure to nano-TiO induced cardiovascular toxicity through oxidative stress, inflammation and apoptosis. J Toxicol Sci 2019; 44: 35-45.

5. Priyanka KP, Kurian A, Balakrishna KM, Varghese T. Toxicological impact of $\mathrm{TiO}_{2}$ nanoparticles on Eudrilus euginiae. IET Nanobiotechnol 2018; 12: 579-84.

6. Ruotolo R, Maestri E, Pagano L, Marmiroli M, White JC, Marmiroli N. Plant response to metal-containing engineered nanomaterials: an omics-based perspective. Environ Sci Technol 2018; 52: 2451-67.

7. Ortelli S, Costa AL, Matteucci P, et al. Silica modification of titania nanoparticles enhances photocatalytic production of reactive oxygen species without increasing toxicity potential in vitro. RSC Adv 2018; 8: 40369-77.

8. Iswarya V, Bhuvaneshwari M, Alex SA, et al. Combined toxicity of two crystalline phases (anatase and rutile) of Titania nanoparticles towards freshwater microalgae: Chlorella sp. Aquat Toxicol 2015; 161: 154-69.

9. Jovanović B. Review of titanium dioxide nanoparticle phototoxicity: developing a phototoxicity ratio to correct the endpoint values of toxicity tests. Environ Toxicol Chem 2015; 34: 1070-7.

10. Noor NFM, Harun AM, Yusof S, Yusoff ME, Mohamad S. Effects of modified hydrothermal nanotitania on the viability of Staphylococcus aureus. Arch Orofac Sci 2018; 13: 1-5.

11. Harun A, Ab Ghani NB, Mohd Noor N, Abas R, Alam MK. Mutagenic properties of modified hydrothermal nanotitania extract. Bangladesh J Med Sci 2020; 19: 159-62.

12. Mukifza A, Yusof S, Awang HB, Farid EM. Synthesis and characterization of titanium dioxide using a caustic hydrothermal with moderate molarity and ratio from synthetic rutile waste. Eur J Sci Technol 2016; 4: 127-30. 